\title{
中学校運動部活動顧問教師のストレッサーに関する研究
}

\section{一運動部活動顧問教師用ストレッサー尺度の作成及び属性間による比較検討ー ${ }^{\dagger}$}

\author{
古川拓 也* 舟橋弘 晃** 横田 匡 俊***,**** \\ 間 野 義 之*****
}

\section{A Study on Teachers' Stressors in Junior High School-Based Extracurricular Sports Activities: Development of a Stressor Scale and Comparison among Attributes ${ }^{\dagger}$}

\author{
Takuya FURUKAWA* , Hiroaki FUNAHASHI ** , Masatoshi YOKOTA***,**** \\ and Yoshiyuki MANO*****
}

\begin{abstract}
The aim of this study was to develop a teacher's stressor scale for junior high schoolbased extracurricular sports activities and to compare cognition of stressors among attributes. The participants of this investigation were 1042 teachers who coach extracurricular sports activities; randomly selected by stratified sampling. Respondents were 373 teachers (males : 293, females : 80). Exploratory factor analysis revealed 7 factors (e.g. time burden of extracurricular sports activities and difficulty of communication with students) that were composed of 24 items. In addition, construct validity and reliability of the scale were confirmed by confirmatory factor analysis and Cronbach's alpha. The result of $t$ test and one-way analysis of variance revealed significant differences between attributes. In this study the validity and reliability of the teacher's stressor scale for junior high school-based extracurricular sports activities were confirmed. The results of comparisons among attributes suggested that different teachers' attributes were also different from the cognition of stressors.
\end{abstract}

Key words : Junior High School-Based Extracurricular Sports Activities, Stressor Scale, Factor Analysis, Comparison of Attributes

\footnotetext{
†原稿受付 2015年 7 月13日 原稿受諾 2015年12月 7 日

*早稲田大学大学院スポーツ科学研究科 テ202-0021 東京都西東京市東伏見 $2-7-5$

**早稲田大学スポーツ科学学術院 =202-0021 東京都西東京市東伏見 $2-7$ - 5

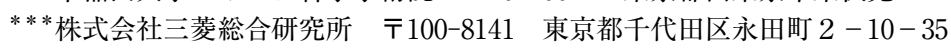

****早稲田大学スポーツビジネス研究所 †202-0021 東京都西東京市東伏見 $2-7$ - 5

*****早稲田大学スポーツ科学学術院 †202-0021 東京都西東京市東伏見 3-4 - 1

* Graduate School of Sport Sciences, Waseda University, 2-7-5, Higashifushimi, Nishitokyo, Tokyo, Japan (202-0021)

** Faculty of Sport Sciences, Waseda University, 2-7-5, Higashifushimi, Nishitokyo, Tokyo, Japan (202-0021)

*** Mitsubishi Research Institute, INC., 2-10-35, Nagatacho, Chiyoda-ku, Tokyo, Japan (100-8141)

**** Research Institute for Sport Business, Waseda University, 2-7-5, Higashifushimi, Nishitokyo, Tokyo, Japan (202-0021)

***** Faculty of Sport Sciences, Waseda University, 3-4-1, Higashifushimi, Nishitokyo, Tokyo, Japan (202-0021)
} 


\section{1. はじめに}

我が国において, 学校の運動部活動は顧問教 師（以下, 顧問）（注 1 ）の積極的な取り組み に支えられてきた ${ }^{1)}$. 実際に, 教師の残業時間 における業務内容に部活動指導が多く挙げられ

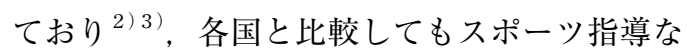

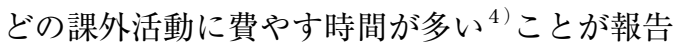
されている. また, 部活動指導の職務としての 曖昧さ ${ }^{5)}$ 6), 時間外指導手当の支給額 ${ }^{7)}$, 顧問 教員の専門性の不足 ${ }^{8)}$ などの指摘があり, 顧問 に関わる問題に関心が寄せられている.

顧問は生徒の人間的な側面を指導する教師の 役割を果たすと同時に, 競技における技能の向 上や試合での勝利といった目標達成のためコー チとしての役割を担わなければならず,「教育 的/競技的二重空間」泉の中で指導を行ってい るといえる。そして，この「教育的/競技的」 な二重の側面により, 顧問は指導場面において 比較的解決が困難であるとされる葛藤に直面す $る^{10)}$. 例えば，競技力の高い部員が公式戦への 出場ではなく, 受験勉強を優先させたいと申し 出てきたときや, 顧問自身の家庭事情と部活動 の事情どちらを優先するべきかなどの葛藤が考 えられよう。このような運動部活動の特徵から 顧問が指導を行う環境は非常に複雑であり, 先 に挙げたような運動部活動に関する様々な課題 の中で部活動の指導を行っていることを鑑みる と, 運動部活動の顧問は多くのストレスフルな 状況・出来事と遭遇していることが推察される.

そこで本研究は, 顧問が運動部活動において 認知しているストレッサーを明らかにし, 顧問 のストレッサー尺度を作成することを目的とす る.さらに, 顧問や部活動の属性によって認知 されるストレッサーの程度が違うことが考えら れるため, 本研究では顧問と部活動の属性によ るストレッサーの認知の違いを明らかにするこ とも目的とする. なお, 本研究では, 中学校の 運動部活動顧問を研究対象とした. 高校は受験 があることで, 部活動へ同じような志向性や目 標を持った部員が集まりやすいことが考えられ
る. 一方で中学は, 多くの生徒は自身が住む学 区内の中学校へ進学する為, 部活動へは多様な 志向性や目標を持った部員が存在していると推 察される。その結果, 学習指導要領における部 活動の取り扱いは中学校と高校に違いは見られ ないが, 中学校の顧問の方が多様な部員に向け た運営の工夫や指導の工夫が求められ，より多 くの困難や葛藤, 不安を抱えていることが考え られる，さらに，中学校の方が運動部活動への 顧問就任率が高い" ${ }^{11)}$. したがって, 本研究では 中学校の顧問に着目することにした.

昨今の運動部活動の指導の充実に向けた取り 組み ${ }^{1)}$ が推進されているように, 運動部活動の 顧問に着目した研究の蓄積は非常に重要である といえる. 政策や学校の計画を立案する際に, 顧問のバーンアウト要因や指導態度を規定する 要因, 体罰に至る経緯など実証された根拠とし て活用可能となるからである。そ様な観点か ら, 顧問が遭遇する出来事や周囲の環境を, 顧 問自身がどの程度ストレッサーとして認知して いるかを明らかにする本研究は, 基礎的研究と 位置付けられ, 発展可能性を有している点で意 義深いと考える.

\section{2. 先行研究の検討}

これまで教師とコーチそれぞれの職業にお いてストレスに着目した研究が行われてき ている.教師のストレスに着目した研究は Kyriacou and Satcliff ${ }^{12)}$ をはじめとして, 海外 や国内に研究の蓄積がみられる $\left.{ }^{13)}-19\right)$. 例えば, Borg et al. ${ }^{13)}$ は, 教師ストレス, 教師の職務満 足, キャリアコミットメントの関係性を検証 し，さらにストレス要因を抽出している。ま た，性別や職務経験など属性ごとの比較を定量 的に行っている. その中で, ストレス要因とし て「児童の問題行動」「時間/資源の困難性」「専 門的理解の必要性」「関係性の欠如」といった 因子が抽出されている. また, Klassen et al. ${ }^{14)}$ は,「教室内ストレス」と「作業負担ストレス」 が職務満足に与える影響と, 媒介変数としての 教師の自己効力感の関係性を明らかにしてい 
る.このように教師のストレスに着目した研究

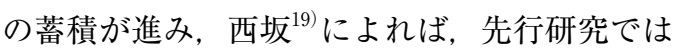
教師のストレッサーの構成概念として主に,「子 どもの問題」「同僚との関係性」「専門性」「多 忙」などが明らかとなっている. さらに, 近年 競技スポーツ場面のストレス研究で, 定性的な 研究を中心にコーチを対象とした研究が行われ ており, コーチが認知するストレッサーとして, パフォーマンスストレッサーと組織的ストレッ サーが抽出されている. パフォーマンススト レッサーは, コーチが経験する選手のパフォー マンスに関すること，もしくはコーチ自身の能 カとパフォーマンスに関することをストレッ サーとしている．組織的ストレッサーは，コー チが属する組織の運営に関連することをスト レッサーとしている20)-22). 例えば, Thelwell et $\mathrm{al}^{21)}$ はエリートアスリートへの指導を行っ ているコーチを対象にインタビュー調査を行っ た結果,「選手のパフォーマンス」,「コーチ自 身のパフォーマンス」の要因から構成されるパ フォーマンスストレッサーと,「環境」,「リー ダーシップ」,「個人」,「チーム」といった要因 を含んだ組織ストレッサーの 2 つの概念をコー チストレッサーとして抽出している.

運動部活動におけるストレス研究は, 渋倉 他 ${ }^{23) 24)}$ が部員生徒を対象に行ってきた。顧問の ストレスに着目した研究は, 渋倉 ${ }^{25)}$ が顧問のス トレッサー尺度作成のための予備的研究と位置 づけて，高校の顧問の悩みや負担の実態を定性 的に明らかにしている. 具体的には,「部員」「活 動環境」「指導力」「時間的負担 $「 「$ 金銭的負担 $「 「$ 体 力的負担」「制度の不整備」「顧問間の人間関係」 の 8つのカテゴリーを顧問の悩みや負担として 分類した. これまで教師やコーチのストレスに ついて様々な検討がなされてきているが,「教 育的/競技的」な二重の役割を併せ持つ運動部 活動の顧問のストレスについては, 渋倉 ${ }^{25}$ の研 究以降散見されない. よって, 渋倉 ${ }^{25)}$ の研究を 発展させ, 定量的な研究を行うことで顧問の認 知するストレッサーの実態を明らかにすること は意義を有すると考えられる。

\section{3. 方法}

\section{1 調査対象および手続き}

調査対象は関東地方における A 県 B 市の中学 校運動部活動の顧問1,042名とした。サンプル の抽出方法は，B市内の地域を行政区ごとに東 西南北の 4 区分, 学校規模を各校のクラス数か ら大中小の 3 区分を設定し，各層に存在する学 校数の比率と比例する対象校数を無作為に抽出 した．全国の公立中学校教職員数は 253,829 人 ${ }^{26)}$ であり，運動部活動顧問教員数を 6 割であると 想定 ${ }^{2)}$ すると 152,297 人が母集団として考えら れる．信頼区間 $95 \%$ ，母集団比率を $50 \%$ ，許容 誤差を $5 \%$ と想定し，必要となるサンプル数の 算出を行った結果，383以上のサンプルが必要 であることが明らかとなった，抽出の際には， 調查票の回収数が383以上となることを想定し た．その結果，48校を抽出し，対象校となった 中学校運動部活動の顧問を調査対象者とした.

調查方法は, A県 B市の教育委員会を介した 郵送法による質問紙調查を行った。調查期間は 2013年10月〜11月であった．質問紙の配布数 は1,042部で，786部を回収（回収率75.4\%）し, 分析に必要となる項目全てに正しく回答したも のを有効回答としたままた，部活動の活動場 所に行き，直接指導をすることが 1 週間のうち 1 度もないと回答した対象者は分析対象外とし た。 その結果，有効回答数は想定していた 383 部より少ない373部（有効回答率 $35.8 \%$ ）となっ た。ただし，本調查で得られた有効回答数は母 集団の許容誤差 $5 \%$ ～6\%内であるため, 本研 究では母集団を代表するサンプルとして問題な いと判断し，373部を以後の分析に用いた。

\section{2 分析項目}

\section{2.1 属性}

属性は, 性別, 年齢, 学校内における主幹教 諭や主任等の責任ある役職の有無, 顧問もしく は副顧問を務めているといった部活動での役 割, 顧問を担当している部活動競技種目の過去 の経験の有無, 1 週間の指導頻度といった顧問 
自身の基本的な属性に加え, 部活動に関する属 性として担当部活動の部員数, 過去 3 年間で最 高位の大会競技成績, 土日の活動時間を設定し た. なお，過去の 3 年間の大会競技成績は「市 大会」「県大会」「関東大会以上」, 土日の活動 時間（注 2）は「4 時間未満」「半日：4 時間 以上」「概ね全日」の 3 つの選択肢から回答を 求めた. 1 週間の指導頻度と部員数は記述式で 回答を求めた.

\section{2.2 ストレッサーに関する項目}

顧問のストレッサー尺度作成に向け定性的 な研究を行っている渋倉 ${ }^{25}$ 拈よび教師ストレッ サー尺度作成を試みた先行研究 ${ }^{16) 17)}$ を参考に, 中学校の運動部活動の顧問に適した内容となる よう項目の修正を行い，44項目を作成した。 な お, 項目作成に際しては, コーチストレス研 究が近年着目され始めた蓄積の少ない分野であ ること, 一方で教師のストレスは研究の蓄積が 十分にある分野であることから, 渋倉の研究 25) のみならず教師のストレッサー尺度の項目を参 考とした。 ただし, 項目作成の際にはコーチの ストレッサーとして明らかとなっている「パ フォーマンスストレッサー」や「組織ストレッ サー」に関連するような項目が含まれるよう考 慮しつつ作成している.

作成された項目については, 顧問の経験を有 する中学校教員 2 名（20年以上経験）と運動部 活動の施策に精通しているスポーツ政策の専門 家 1 名, スポーツ政策を専攻とする大学院生 6 名によって行われた，まず, 中学校教員 2 名と スポーツ政策の専門家 1 名によって, 作成され た項目の内容は顧問が経験し得る出来事および 状況として適切かどうか検討し, 大学院生 6 名 によって, それらの項目の意味内容に誤解が生 じないかどうか, 文言は適切かどうかが検討さ れた. その結果, 項目の修正・削除・追加を行 い最終的に43項目が作成された。

ラザルス・フォルクマン ${ }^{27)}$ は, 心理的ストレ スの感じ方が個人によって異なることに着目 し, 個人のストレッサーに対する認知的評価を 重視している．認知的評価は，個人にとっての
妿威性を評価する 1 次的評価と, 対処可能性 を評価する 2 次的評価の 2 つの過程が存在す る。これまでストレスの認知的評価モデルをも とに様々なストレッサー尺度が作成されてきた

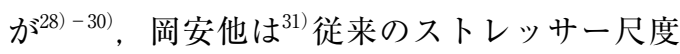
は日常で経験する出来事の嫌悪性のみを評価し ており, 実際にどの程度その出来事に直面して いるかは言及できないとしている。 そこで本 研究は岡安他 ${ }^{31)}$ を参考に, 項目によって示され た出来事を経験する頻度（ 4 件法：1. 全くな かった，2．ときどきあった， 3 ．しばしばあっ た，4．よくあった）と，その出来事の嫌悪性 （4件法：1. 全く嫌ではなかった，2．少し嫌 だった，3．嫌だった，4．非常に嫌だった） について 2 段階での回答を求めた. 経験頻度が

$「 1$ ．全くなかった」もしくは嫌悪性が「1． 全く嫌ではなかった」と評価された場合, その 出来事の衝撃性は無いとみなされる。つまり, ストレッサーとして認知されていない状態であ ると判断される。このことから，「1．全くな かった」と経験頻度が評価された場合は, 嫌悪 性について「1，全く嫌ではなかった」の回答 とみなし, 回答を求めなかった.

\section{3 分析方法}

3. 3.1 分析 1 : 中学校運動部活動顧問教師の

\section{ストレッサー尺度の作成}

岡安他 ${ }^{31)}$ に従い, ストレッサーに関する項目 の経験頻度と嫌覀性の回答選択肢「1〜4」に $\lceil 0 \sim 3 」 の$ 得点を与え, それらを積算したも のをストレッサー得点として分析に用いた.

項目の弁別力の検討および尺度の内的整合性 を高めるためにItem - Total相関分析（以下， IT相関分析）を行った. IT相関分析は，相関 係数が $\mathrm{r}=.40^{32}$ に満たない項目を削除対象と した．なお，その出来事がどの程度共通して経 験されているものなのか, もしくはどの程度嫌 悪を感じさせるものなのかの割合を示す経験率 と嫌覀率の算出（注 3）も行った.

ストレッサーの構成概念の検討を探索的因 子分析にて行った。因子負荷量が. $40^{32)}$ に満た 
ない項目を削除対象とした。 その後, 探索的 因子分析によって得られた構成概念を仮説モ デルとして, 構成概念妥当性を確認的因子分 析によって検討した. 確認的因子分析の際に は, 尺度の簡便化と因子の項目が 4 項目であ る時に最も妥当性の高い值が得られるという 先行研究 ${ }^{33)}$ の指摘を考慮し, 探索的因子分析で 得られた各因子の上位 4 項目を採用した。構 成概念の妥当性を検証するための指標として GFI (Goodness of fit index), AGFI (Adjusted goodness of fit index), CFI (Comparative fit index), RMSEA (Root mean square error of approximation）を用いた. 収束的妥当性を示 すためAVE (平均分散抽出) を算出し, 弁別 的妥当性を検証するため因子間相関の平方と AVEの比較を行った。モデルの適合度指標は,

GFI, AGFI, CFIが.90以上で当てはまりが良 いと判断され, RMSEAは.05以下で当てはま りが良く，.10以上で当てはまりが悪いと判断 される ${ }^{34)}$. さらに, 適合度指標が著しく悪い值 でなければ内容的妥当性等の総合的な観点から 因子構造の妥当性を検証する必要性が指摘され ている ${ }^{35) 36)}$ A AVEは.50以上, 因子間相関の平 方とAVEの比較では, 各因子のAVEが因子間 相関の平方よりも大きい值を示すことを基準值 とした ${ }^{37)}$. 尺度の信頼性を検証するために, 内 的整合性の值を示すChronbachの $a$ 係数を算 出した. $\alpha$ 係数の基準值は.70以上とした ${ }^{32)}$.

\section{3.2 分析 2 : 属性間によるストレッサー下 位尺度得点の比較}

属性とストレッサー下位尺度得点の比較を行 うため, ストレッサー尺度の下位尺度得点を従 属変数, 顧問の基本的属性と部活動の属性を独 立変数として, 独立サンプルの $\mathrm{t}$ 検定もしくは 一元配置分散分析を行った。一元配置分散分析 にて有意な差がみられた場合は, Bonferoni法 を用いて多重比較を行った。 なお, 顧問の指導 頻度と部員数は, 分析の際にそれぞれ 3 つの群 に分類した。指導頻度は 1 週間のうちに 1 日・ 2 日指導する顧問を低頻度指導群，3 日 4 日
指導する顧問を中頻度群，5 日以上指導する顧 問を高頻度群と分類した。部員数は，小規模を 5 人から 24 人, 中規模を 25 人から 40 人, 大規模 を41人から 120 人とした.

以上の分析には, 統計解析ソフトSPSS statistics ver. 22およびAmos ver. 22を用いた。

\section{4. 結果}

\section{1 調査対象者の特徵}

調査対象者の特徽について表 1 にまとめた. 男性が $78.6 \%$, 年齢の平均は 37.2 歳で, 20 歳代 が最も多く $33.2 \%$ となっている。保健体育科を 指導しているのは $22.8 \%$, 部活動において顧 問を担当しているのが $72.9 \%$, 副顧問が $27.1 \%$ となった、日本体育協会が実施した調查 ${ }^{8)} に$ よると, 中学校の運動部活動指導者は男性が $71.5 \%$, 年齢の平均は39.6歳で, 保健体育科 を指導しているのは $19.8 \%$ と報告されている. よって, 本調查によって得られた対象者は概ね 運動部活動顧問の特徵を捉えていると考えられ る. その他の対象者の特徵は, 表 1 を参照され たい.

\section{2 尺度の信頼性および妥当性の検討}

ストレッサーに関する43項目の記述統計結果 および経験率と嫌悪率を表 2 に示した。 経験率 は26.0\%-97.1\%，嫌悪率は $23.6 \%-89.5 \%$ を示 した. 岡安他 ${ }^{31)}$ では, 対象者の $90 \%$ 以上が 0 点 とした項目を削除対象としているが，本研究に おいては経験率もしくは嫌悪率が10\%以下の 項目，つまり $90 \%$ 以上が 0 点を示した項目は無 かった。したがって，全ての項目が経験され嫌 悪感を抱く内容として認知されている. 弁別力 のある項目の検討および，内的整合性を高める ために行ったIT相関分析の結果, 7 項目が $\mathrm{r}$ $=.40$ 以上を満たさず削除対象となった.

分析対象となった 36 項目を用いて探索的因子 分析（主因子法, 回転なし）を行った。固有值 の減退率および因子の解釈可能性から 7 因子構 造が妥当であると判断された。 そこで， 7 因子 構造を仮定して再度探索的因子分析（主因子法, 
表 1 対象者の特徵

\begin{tabular}{|c|c|c|c|c|c|}
\hline & & $\mathrm{n}$ & $\%$ & $\mathrm{M}$ & SD \\
\hline \multirow[t]{2}{*}{ 性別 } & 男性 & 293 & 78.6 & & \\
\hline & 女性 & 80 & 21.4 & & \\
\hline \multirow[t]{5}{*}{ 年齢 } & & & & 37.2 & 11.1 \\
\hline & 20歳代 & 124 & 33.2 & & \\
\hline & 30歳代 & 118 & 31.6 & & \\
\hline & 40歳代 & 50 & 13.4 & & \\
\hline & 50歳以上 & 81 & 21.7 & & \\
\hline \multirow[t]{2}{*}{ 指導教科 } & 保健体育科 & 85 & 22.8 & & \\
\hline & その他教科 & 288 & 77.2 & & \\
\hline \multirow[t]{2}{*}{ 校内での役職 } & 役職あり & 117 & 31.4 & & \\
\hline & 役職なし & 256 & 68.6 & & \\
\hline \multirow[t]{2}{*}{ 部活動での役割 } & 顧問 & 272 & 72.9 & & \\
\hline & 副顧問 & 101 & 27.1 & & \\
\hline \multirow[t]{4}{*}{ 指導頻度 } & & & & 4.2 & 1.8 \\
\hline & 低頻度 & 82 & 22.0 & & \\
\hline & 中頻度 & 118 & 31.6 & & \\
\hline & 高頻度 & 173 & 46.4 & & \\
\hline \multirow[t]{2}{*}{ 過去の競技経験 } & 経験あり & 236 & 63.3 & & \\
\hline & 経験なし & 137 & 36.7 & & \\
\hline \multirow[t]{4}{*}{ 部員数 } & & & & 36.1 & 20.6 \\
\hline & 小規模 & 130 & 34.9 & & \\
\hline & 中規模 & 130 & 34.9 & & \\
\hline & 大規模 & 113 & 30.3 & & \\
\hline \multirow[t]{3}{*}{ 過去 3 年間の成績 } & 市大会 & 167 & 44.8 & & \\
\hline & 県大会 & 149 & 39.9 & & \\
\hline & 関東大会以上 & 57 & 15.3 & & \\
\hline \multirow[t]{3}{*}{ 土日の活動時間 } & 4 時間未満 & 90 & 24.1 & & \\
\hline & 半日：4 時間以上 & 252 & 67.6 & & \\
\hline & 概ね全日 & 31 & 8.3 & & \\
\hline
\end{tabular}

プロマックス回転）を行った。さらに因子負荷 量が.40に満たなかった 3 項目を除き探索的因 子分析を行った結果, 7 因子構造であることが 確認された. 次に, 尺度の簡便化と先行研究33) の指摘から, 各因子において上位 4 項目の項目 を用いて再度探索的因子分析を行った。 その結 果, 7 因子 24 項目が抽出された（表 3). 各因 子の因子名と定義を表 4 に示す。ただし，第 4 因子から第 7 因子にかけては 3 項目の因子と なったが, 顧問が認知するストレッサーを構成 する因子として，3 項目のまま用いた。
次いで, 7 因子 24 項目の構成概念妥当性を確 認するために, 確認的因子分析を行った（図 1 ). その結果, モデル適合度は $\mathrm{GFI}=.88, \mathrm{AGFI}$ $=.84, \mathrm{CFI}=.92, \mathrm{RMSEA}=.07$ となった。収 束的妥当性の值を示す AVEは. 48 - .71の值を 示した (表 5). 弁別的妥当性の検証の結果, 全てのAVEが各因子間相関の平方より大きい 值を示したため弁別的妥当性が確認された（表 5 ). 第 6 因子「学校内雲囲気との相違 (AVE $=.47) 」 に は$, 収束的妥当性が示されなかった が，弁別的妥当性の検証においては因子の妥当 
表 2 ストレッサーに関する項目の記述統計および経験率と嫌悪率

\begin{tabular}{|c|c|c|c|c|c|c|c|c|c|c|}
\hline \multirow{2}{*}{ 項目 } & \multicolumn{5}{|c|}{$\begin{array}{l}\text { 頻度 } \\
\end{array}$} & \multicolumn{5}{|c|}{ 嫌悪 } \\
\hline & $\min$. & Max. & $\mathrm{M}$ & SD & 経験率 & $\min$. & Max. & $\mathrm{M}$ & SD & 嫌恵率 \\
\hline (1) 練習を直接指導できない日があること & 0 & 3 & 1.94 & .90 & 96.8 & 0 & 3 & 1.43 & .94 & 83.1 \\
\hline (2) 試合や練習をするのに十分な部員数が確保できないこと & 0 & 3 & .95 & 1.03 & 57.4 & 0 & 3 & .92 & 1.08 & 50.1 \\
\hline (3) 部員との人間関係がうまくいかないこと & 0 & 3 & .96 & .74 & 75.3 & 0 & 3 & 1.30 & 1.09 & 70.2 \\
\hline (4) 校務が忙しく, 部活動指導が満足にできないこと & 0 & 3 & 2.01 & .88 & 97.1 & 0 & 3 & 1.71 & .98 & 89.5 \\
\hline (5) 部員の考えていることが理解できないこと & 0 & 3 & 1.07 & .66 & 85.5 & 0 & 3 & 1.14 & .93 & 72.9 \\
\hline (6) 部員に向上心が欠けていること & 0 & 3 & 1.43 & .83 & 89.8 & 0 & 3 & 1.54 & .99 & 83.4 \\
\hline (7) 顧問間もしくは外部指導者と価値観の違いを感じること & 0 & 3 & .72 & .89 & 48.5 & 0 & 3 & .67 & .97 & 40.2 \\
\hline （8）自分自身と部員の活動意欲に差を感じること & 0 & 3 & 1.27 & .85 & 83.9 & 0 & 3 & 1.23 & .93 & 75.9 \\
\hline (9) 自分自身の指導力と部員の競技力に差を感じること & 0 & 3 & 1.29 & .99 & 77.2 & 0 & 3 & .96 & .97 & 60.3 \\
\hline (10) 部員が上達しないこと & 0 & 3 & 1.24 & .91 & 79.9 & 0 & 3 & .81 & .81 & 60.3 \\
\hline 旨導に, 生徒からあからさまに不 & 0 & 3 & .67 & 69 & 56.3 & 0 & 3 & .84 & .97 & 52.3 \\
\hline しくは外部指導者の, 生徒への & 0 & 3 & .58 & .77 & 44.2 & 0 & 3 & .67 & .96 & 39.9 \\
\hline (13) 保護者と運動部活動に対する価值観の違い & 0 & 3 & 1.05 & .84 & 74.0 & 0 & 3 & 1.17 & 1.04 & 68.6 \\
\hline (14) 部活動によって, 土日が無いような生活を & 0 & 3 & 2.09 & 1.06 & 89.8 & 0 & 3 & 1.25 & 1.03 & 71.3 \\
\hline （15）他の顧問もしくは外部指導者と意思の蹯通がはかれていないこと & 0 & 3 & .62 & .81 & 45.8 & 0 & 3 & .61 & .89 & 39.4 \\
\hline (16) 学校全体と自分自身の部活動に対する志気に差を感じること & 0 & 3 & .77 & .91 & 51.7 & 0 & 3 & .70 & .93 & 45.0 \\
\hline （17）部員が指導内容を理解しないこと & 0 & 3 & .94 & .82 & 69.7 & 0 & 3 & .70 & .75 & 54.7 \\
\hline 部活動に対する価值観の違い & 0 & 3 & .50 & .78 & 37.0 & 0 & 3 & .56 & .91 & 33.8 \\
\hline 意欲の差があると感じること & 0 & 3 & 1.60 & .90 & 91.2 & 0 & 3 & 1.12 & .87 & 74.3 \\
\hline て部員とゆっくり語り合う時間が取れないこと & 0 & 3 & 1.68 & .94 & 91.4 & 0 & 3 & 1.47 & .95 & 85.5 \\
\hline 力が不足していると感じること & 0 & 3 & 1.86 & .94 & 94.6 & 0 & 3 & 1.65 & .99 & 87.7 \\
\hline 部活動の両立が難しくなったこと & 0 & 3 & 1.59 & .98 & 86.6 & 0 & 3 & 1.47 & 1.02 & 81.8 \\
\hline いてくれないこと & 0 & 3 & .92 & .69 & 76.4 & 0 & 3 & .97 & .87 & 67.3 \\
\hline す時間外勤務の負担が大きす & 0 & 3 & 1.80 & 1.12 & 84.2 & 0 & 3 & 1.32 & 1.08 & 73.2 \\
\hline をするのに十分な活動時間が確保できないこと & 0 & 3 & 1.43 & .99 & 81.5 & 0 & 3 & 1.22 & .97 & 74.8 \\
\hline 疎通がうまくいかないこと & 0 & 3 & .88 & .66 & 74.5 & 0 & 3 & .87 & .80 & 66.0 \\
\hline 時間が多く，校務に十分な & 0 & 3 & 1.07 & .92 & 71.0 & 0 & 3 & .94 & .92 & 62.5 \\
\hline 対して，保護者から一方的な批判を受けたこと & 0 & 3 & .75 & .74 & 60.3 & 0 & 3 & 1.12 & 1.15 & 58.2 \\
\hline 努力しても, 生徒の保護者から満足な評価を受けられないこと & 0 & 3 & .76 & .82 & 56.6 & 0 & 3 & .84 & 1.02 & 50.7 \\
\hline に対して自己負担があること & 0 & 3 & 1.35 & 1.09 & 73.5 & 0 & 3 & .97 & 1.06 & 55.8 \\
\hline 活動指導のあり方に，保護者からあからさまに & 0 & 3 & .60 & .76 & 47.5 & 0 & 3 & .82 & 1.07 & 45.0 \\
\hline 功いてもなかなか結果 (大会での) & 0 & 3 & 1.24 & 1.00 & 74.5 & 0 & 3 & .90 & .93 & 59.2 \\
\hline (33) मे & 0 & 3 & 1.12 & 1.05 & 65.7 & 0 & 3 & .95 & 1.02 & 57.1 \\
\hline て，保護者の協力力 & 0 & 3 & .53 & .71 & 42.9 & 0 & 3 & .54 & .79 & 38.1 \\
\hline 舌動の指導に同僚からの理解を得ていないと感じること & 0 & 3 & .34 & .66 & 26.0 & 0 & 3 & .36 & .74 & 23.6 \\
\hline 員が言うことを聞いてくれないこと & 0 & 3 & .66 & .75 & 52.5 & 0 & 3 & .67 & .87 & 46.6 \\
\hline の指導が体力的に負担になること & 0 & 3 & 1.01 & 1.02 & 60.9 & 0 & 3 & .84 & .99 & 52.5 \\
\hline 時間外勤務に, 十分な手当てが確保されていないこと & 0 & 3 & 2.05 & 1.14 & 84.5 & 0 & 3 & 1.84 & 1.18 & 80.7 \\
\hline 期待が大きいと感じること & 0 & 3 & .83 & .93 & 55.2 & 0 & 3 & .45 & .73 & 33.5 \\
\hline （趣味など）がなかなか持てないこと & 0 & 3 & 1.67 & 1.19 & 77.2 & 0 & 3 & 1.28 & 1.14 & 67.8 \\
\hline 日は半日の指導や練習試合があり, 自分の時間に余裕が無いこと & 0 & 3 & 1.93 & 1.10 & 86.9 & 0 & 3 & 1.38 & 1.08 & 75.6 \\
\hline 今や練習をするのに十分な場所が確保できないこと & 0 & 3 & 1.34 & 1.12 & 71.8 & 0 & 3 & 1.17 & 1.08 & 65.7 \\
\hline (43) 部活動の顧問という職務が精神的負担に感じること & 0 & 3 & .88 & 1.00 & 55.2 & 0 & 3 & .88 & 1.05 & 51.2 \\
\hline
\end{tabular}

項目分析削除対象 (1) $: \mathrm{r}=.36, \quad(2) ; \mathrm{r}=.29, \quad(9) ;=.39, \quad(10)=.37, \quad(25) ; \mathrm{r}=.37, \quad(32) ; \mathrm{r}=.37, \quad(42) ; \mathrm{r}=.36$

性を示すことができた。 したがって，以上の結 果と先行研究の指摘 ${ }^{35}$ (36) $お$ よび内容的妥当性の 観点から, 本分析結果の因子構造は許容可能な モデルであると判断した. よって本研究では, 7 因子 24 項目の因子構造が妥当なモデルとして 採用した。

尺度の信頼性を検証するために内的整合性の 值を示すChronbachの $\alpha$ 係数を算出した（表
3). $\alpha$ 係数は.72-.91の值を示し, 全ての因 子において基準值の $\alpha=.70$ 以上を満たしてい ることから尺度の信頼性が確認された。

\section{3 属性による比較}

属性を独立変数, ストレッサー下位尺度得点 を従属変数として独立サンプルの $\mathrm{t}$ 検定（表 6) 及び，一元配置分散分析（表7）を行った. 
表 3 探索的因子分析結果（主因子法, プロマックス回転)およびChronbachの $a$ 係数

\begin{tabular}{|c|c|c|c|c|c|c|c|c|}
\hline \multirow{2}{*}{ 項目 } & \multicolumn{7}{|c|}{ 因子負荷量 } & \multirow{2}{*}{$\alpha$} \\
\hline & F1 & F2 & F3 & F4 & F5 & F6 & F7 & \\
\hline (41) 土日は半日の指導や練習試合があり, 自分の時間に余裕が無いこと & 1.00 & -.06 & -.04 & .00 & -.07 & .03 & .02 & .90 \\
\hline (40) 自分の時間 (趣味など) がなかなか持てないこと & .91 & -.07 & -.02 & .03 & -.01 & .02 & -.07 & \\
\hline （24）部活動に費やす時間外勤務の負担が大きすぎること & .74 & .08 & .04 & -.06 & .05 & -.10 & .06 & \\
\hline (14) 部活動によって, 土日が無いような生活を続けていること & .73 & .05 & .04 & .03 & -.02 & .06 & -.02 & \\
\hline (23) 部員が心を開いてくれないこと & -.05 & .95 & -.07 & -.01 & .03 & .00 & -.03 & .88 \\
\hline (26) 部員との意思疎通がうまくいかないこと & .00 & .83 & .03 & -.03 & .02 & -.06 & .11 & \\
\hline (3) 部員との人間関係がうまくいかないこと & .06 & .71 & .05 & -.02 & -.04 & .16 & -.08 & \\
\hline (11) 自分自身の指導に, 生徒からあからさまに不信な態度をとられたこと & .01 & .70 & .01 & .10 & -.06 & .04 & -.08 & \\
\hline （31）自分自身の部活動指導のあり方に，保護者からあからさまに不信な態度を取られたこと & -.01 & .11 & .91 & -.01 & -.06 & -.09 & .02 & .89 \\
\hline （28）部活動指導に対して，保護者から一方的な批判を受けたこと & -.04 & .03 & .84 & -.03 & .03 & -.05 & .05 & \\
\hline （29）部活動指導を努力しても, 生徒の保護者から満足な評価を受けられないこと & .08 & .04 & .82 & .01 & .00 & -.03 & .01 & \\
\hline （13）保護者と運動部活動に対する価値観の違いを感じること & -.02 & -.20 & .72 & .05 & .06 & .21 & -.08 & \\
\hline （15）他の顧問もしくは外部指導者と意思の疎通がはかれていないこと & .02 & .00 & -.02 & .95 & .00 & -.03 & .03 & .81 \\
\hline (7) 顧問間もしくは外部指導者と価値観の違いを感じること & .02 & -.04 & .06 & .80 & -.01 & -.06 & -.04 & \\
\hline (12) 他の顧問もしくは外部指導者の, 生徒への態度に疑問を感じること & -.10 & .23 & -.05 & .49 & .05 & .13 & .05 & \\
\hline (20) 校務に追われて部員とゆっくり語り合う時間が取れないこと & -.07 & .05 & -.01 & -.01 & .90 & -.07 & -.04 & .79 \\
\hline (4) 校務が忙しく，部活動指導が満足にできないこと & -.05 & -.14 & .05 & .04 & .72 & .05 & .00 & \\
\hline (22) 教科, 分掌, 部活動の両立が難しくなったこと & .27 & .13 & -.04 & -.05 & .58 & .01 & .07 & \\
\hline (6) 部員に向上心が欠けていること & .00 & .09 & -.08 & -.09 & -.05 & .88 & .00 & .75 \\
\hline (8) 自分自身と部員の活動意欲に差を感じること & -.03 & .06 & .16 & -.01 & -.01 & .65 & .07 & \\
\hline (19)部員間に活動意欲の差があると感じること & .10 & -.03 & .02 & .13 & .08 & .45 & .01 & \\
\hline (16) 学校全体と自分自身の部活動に対する志気に差を感じること & -.04 & -.15 & -.03 & .02 & .04 & .10 & .74 & .72 \\
\hline （18）管理職と運動部活動に対する価値観の違いを感じること & .05 & .07 & .00 & .08 & -.08 & -.10 & .69 & \\
\hline (35) 部活動の指導に同僚からの理解を得ていないと感じること & -.03 & .01 & .03 & -.08 & .02 & .04 & .67 & \\
\hline 因子間相関 & F1 & F2 & F3 & F4 & F5 & F6 & F7 & \\
\hline $\mathrm{F} 1$ & - & .45 & .30 & .27 & .36 & .35 & .17 & \\
\hline $\mathrm{F} 2$ & & - & .44 & .38 & .21 & .54 & .36 & \\
\hline F3 & & & - & .43 & .22 & .41 & .44 & \\
\hline $\mathrm{F} 4$ & & & & - & .20 & .41 & .39 & \\
\hline F5 & & & & & - & .25 & .48 & \\
\hline F6 & & & & & & - & .30 & \\
\hline F7 & & & & & & & - & \\
\hline
\end{tabular}

\section{表 4 因子名と定義}

因子名

第 1 因子：部活動の時間的負担

第 2 因子 : 部員との意思疎通困難

第 3 因子 : 保護者の批判的態度

第 4 因子 : 他の指導者との人間関係の悪さ

第 5 因子：指導時間の不足

第 6 因子：活動意欲の低い部員

第 7 因子: 学校内雾囲気との相違

\section{定義}

部活動への従事が負担に感じること

部員との意思疎通が上手くいかないこと

保護者の部活動指導に対する批判的な態度

他の指導者と人間関係が上手くいかないこと

部活動を直接指導する時間が足りないこと

部活動に取り組む意欲が低い部員のこと

管理職や同僚など, 学校内の部活動に対する意識が異なること
その結果, 顧問の個人属性では, 性別, 年歯, 指導教科, 校内での役職有無, 部活動での役割, 過去の競技経験, 部活動指導頻度において, 統 計的に有意な差がみられた。部活動に関連する 属性では, 過去 3 年間の競技成績において, 統
計的な有意な差がみられた。

性別では「保護者の批判的な態度」( t $=2.42, \mathrm{p}<.05 ）$ の々有意な差がみられ，女 性に比べ男性の方が高い得点となった．年齢に よる比較では, 年代別の 4 群に分類し分析を 


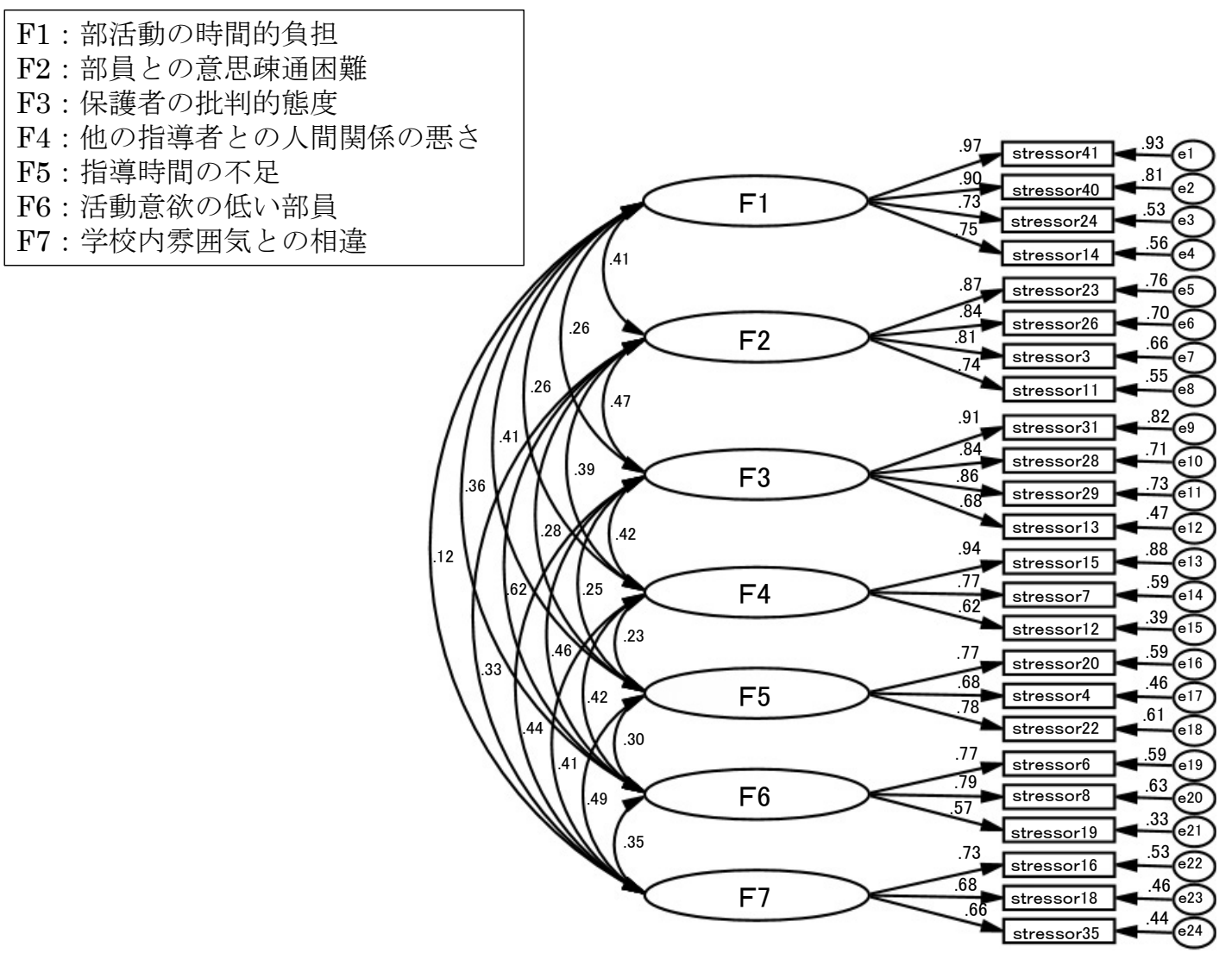

図 1 運動部活動顧問のストレッサー尺度 確認的因子分析モデル

表 5 因子間相関の平方とAVEの比較

\begin{tabular}{llllllll}
\hline \multicolumn{1}{c}{ 因子 } & $\mathrm{F} 1$ & $\mathrm{~F} 2$ & $\mathrm{~F} 3$ & $\mathrm{~F} 4$ & $\mathrm{~F} 5$ & $\mathrm{~F} 6$ & $\mathrm{~F} 7$ \\
\hline 部活動の時間的負担 & $.71^{\mathrm{a}}$ & .17 & .07 & .13 & .07 & .16 & .02 \\
部員との意思疎通困難 & & $.67^{\mathrm{b}}$ & .22 & .39 & .16 & .08 & .11 \\
保護者の批判的態度 & & & $.68^{\mathrm{c}}$ & .21 & .18 & .06 & .19 \\
他の指導者との人間関係の悪さ & & & & $.62^{\mathrm{d}}$ & .18 & .09 & .13 \\
指導時間の不足 & & & & & $.55^{\mathrm{e}}$ & .05 & .17 \\
活動意欲の低い部員 & & & & & & $.52^{\mathrm{f}}$ & .24 \\
学校内需囲気との相違 & & & & & & & $.48^{\mathrm{g}}$ \\
\hline
\end{tabular}

$\mathrm{a}$ ；「部活動の時間的負担」の AVE值, b ; 「部員との意思疎通困難」の AVE值, $\mathrm{c}$; 「保護者の批判的態 度」の AVE 值, $\mathrm{d}$; 「他の指導者との人間関係の悪さ」の AVE值, $\mathrm{e}$; 指導時間の不足」の AVE值, $\mathrm{f}$; 「活動意欲の低い部員」のAVE值, g ; 「学校内䨌囲気との相違」の AVE 值

行った。その結果,「指導時間の不足」( $\mathrm{F}=7.53$, $\mathrm{p}<.001)$, 「活動意欲の低い部員」（F=3.96, $\mathrm{p}<.05)$ と, 「学校内䨌囲気との相違」（F=
5.48, p < .05）の 3 因子に有意な差がみられた。 多重比較の結果では,「指導時間の不足」では, 30 歳代が50歳以上と20歳代より有意に高い得点 


\section{表 6 属性間による下位尺度得点の比較（ $\mathrm{t}$ 検定）}

\begin{tabular}{|c|c|c|c|c|c|c|c|c|c|c|c|c|c|c|c|c|c|c|c|c|c|c|}
\hline & & \multicolumn{3}{|c|}{ 部活動の時間的負担 } & \multicolumn{3}{|c|}{ 部員との意思踈通困難 } & \multicolumn{3}{|c|}{ 保護者の批判的態度 } & \multicolumn{3}{|c|}{ 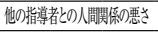 } & \multicolumn{3}{|c|}{ 指導時間の不足 } & \multicolumn{6}{|c|}{ 活動意欲の低い部員 学校内䨌囲気との相違 } \\
\hline & & M & $\mathrm{SD}$ & $\mathrm{t}$ 值 & $\mathrm{M}$ & SD & $\mathrm{t}$ 值 & $\mathrm{M}$ & $\mathrm{SD}$ & $\mathrm{t}$ 值 & $\mathrm{M}$ & $\mathrm{SD}$ & $\mathrm{t}$ 值 & $\mathrm{M}$ & SD & $\mathrm{t}$ 值 & $\mathrm{M}$ & $\mathrm{SD}$ & $\mathrm{t}$ 值 & $\mathrm{M}$ & $\mathrm{SD}$ & $\mathrm{t}$ 值 \\
\hline \multirow[t]{2}{*}{ 性別 } & 男性（n=293） & 12.30 & 11.58 & \multirow{2}{*}{1.03} & 5.12 & 5.61 & \multirow{2}{*}{.52} & 6.11 & 7.23 & \multirow{2}{*}{$2.42^{*}$} & 3.04 & 5.17 & \multirow{2}{*}{.55} & 9.97 & 7.46 & \multirow{2}{*}{.19} & 6.75 & 5.61 & \multirow{2}{*}{.67} & 2.68 & 4.45 & \multirow{2}{*}{.01} \\
\hline & 女性 ( $\mathrm{n}$ & 13.79 & 10.90 & & 5.50 & 6.40 & & 4.13 & 6.29 & & 3.39 & 4.61 & & 9.79 & 7.49 & & 7.24 & 6.27 & & 2.68 & 4.71 & \\
\hline \multirow[t]{2}{*}{ 指導教科 } & 保健体育教員（n=85） & 10.27 & 10.79 & \multirow{2}{*}{$2.62^{*}$} & 4.31 & 5.56 & \multirow{2}{*}{1.63} & 5.93 & 7.67 & \multirow{2}{*}{.36} & 2.58 & 4.43 & \multirow{2}{*}{1.11} & 9.78 & 7.13 & \multirow{2}{*}{.21} & 7.18 & 6.14 & \multirow{2}{*}{.58} & 2.54 & 4.46 & \multirow{2}{*}{.32} \\
\hline & その他教科（n=288） & 13.31 & 11.55 & & 5.47 & 5.83 & & 5.61 & 6.91 & & 3.27 & 5.22 & & 9.97 & 7.56 & & 6.76 & 5.64 & & 2.72 & 4.52 & \\
\hline \multirow[t]{2}{*}{ 校内での役職 } & 役職あり（n = 117） & 11.37 & 10.20 & \multirow{2}{*}{1.52} & 4.08 & 3.54 & \multirow{2}{*}{$3.14^{*}$} & 5.06 & 4.29 & \multirow{2}{*}{1.43} & 2.98 & 4.66 & \multirow{2}{*}{.33} & 9.45 & 6.98 & \multirow{2}{*}{.83} & 6.21 & 4.58 & \multirow{2}{*}{1.66} & 2.47 & 3.97 & \multirow{2}{*}{.60} \\
\hline & 役職なし（n=256） & 13.19 & 11.94 & & 5.71 & 6.50 & & 5.97 & 8.03 & & 3.17 & 5.23 & & 10.14 & 7.67 & & 7.16 & 6.20 & & 2.77 & 4.72 & \\
\hline \multirow[t]{2}{*}{ 部活動での役職 } & 顧問（n = 272） & 12.24 & 11.56 & \multirow{2}{*}{1.06} & 5.32 & 5.89 & & 6.05 & 7.16 & & 2.99 & 5.10 & & 10.25 & 7.34 & & 6.79 & 5.70 & & 3.06 & 4.91 & \\
\hline & 副顧問（n = 101） & 13.65 & 11.11 & & 4.89 & 5.49 & . & 4.71 & 6.80 & 1.02 & 3.45 & 4.92 & .10 & 9.06 & 7.73 & 1.57 & 7.03 & 5.93 & (5) & 1.66 & 2.91 & 5.35 \\
\hline 過去の競技経験 & 経験あり（n = 236） & 11.73 & 10.76 & & 5.10 & 5.75 & & 5.74 & 6.92 & & 3.21 & 5.32 & & 10.51 & 7.71 & & 6.89 & 6.03 & & 2.83 & 4.80 & \\
\hline & 経験なし（n =137） & 14.15 & 12.42 & 1.91 & 5.37 & 5.86 & .44 & 5.60 & 7.37 & .10 & 2.95 & 4.57 & .40 & 8.92 & 6.91 & 2.00 & 6.81 & 5.27 & .12 & 2.41 & 3.92 & .93 \\
\hline
\end{tabular}

表 7 属性間による下位尺度得点の比較（一元配置分散分析）

\begin{tabular}{|c|c|c|c|c|c|c|c|c|c|c|c|c|c|c|c|c|c|c|c|c|c|c|}
\hline & & \multicolumn{3}{|c|}{ 部活動の時間的負担 } & \multicolumn{3}{|c|}{ 部員との意思踈通困難 } & \multicolumn{3}{|c|}{$\begin{array}{l}\text { 保護者の批判的態度 } \\
\end{array}$} & \multicolumn{3}{|c|}{ 他の指導者との人間関佰の悪さ } & \multicolumn{3}{|c|}{ 指導時間の不足 } & \multicolumn{3}{|c|}{ 活動意欲の低い部員 } & \multicolumn{3}{|c|}{ 学校内雰囲気との相違 } \\
\hline & & M & SD & F值 & M & SD & F値 & M & SD & F值 & M & SD & F値 & M & SD & F値 & M & SD & F值 & M & SD & F值 \\
\hline \multirow[t]{4}{*}{ 年齡 } & 20歳代 $(\mathrm{n}=124)$ & 12.84 & 12.02 & & 6.02 & 7.40 & \multirow{4}{*}{2.50} & 5.48 & 7.78 & \multirow{4}{*}{1.96} & 2.90 & 4.74 & \multirow{4}{*}{1.65} & 8.53 & 6.44 & $7.53^{* 8 *}$ & 8.02 & 6.80 & \multirow{4}{*}{$\begin{array}{l}3.96^{*} \\
\text { 200歲代> } \\
\text { 50藏以上 }\end{array}$} & 1.81 & 3.80 & $5.48^{*}$ \\
\hline & 30 歳代 $(\mathrm{n}=118)$ & 13.33 & 11.61 & \multirow{3}{*}{.46} & 5.50 & 5.53 & & 6.22 & 7.62 & & 3.88 & 6.20 & & 12.07 & 7.83 & 20歲代, & 6.96 & 5.71 & & 3.67 & 5.31 & $\begin{array}{l}30.40 \\
20 \text { 歳代, }\end{array}$ \\
\hline & 40歳代（n=50） & 12.30 & 11.27 & & 4.50 & 3.56 & & 7.14 & 7.26 & & 3.10 & 5.14 & & 11.44 & 8.44 & 50歳以上 & 6.30 & 4.85 & & 3.78 & 5.35 & 50歲以上 \\
\hline & 50 歳以上 $(\mathrm{n}=81)$ & 11.44 & 10.46 & & 3.94 & 3.99 & & 4.33 & 4.39 & & 2.32 & 3.17 & & 8.01 & 6.82 & $<30$ 歲代 & 5.28 & 4.01 & & 1.88 & 3.02 & $<30$ 歳代 \\
\hline \multirow{3}{*}{ 指導頻度 } & 低頻度（n=82） & 16.88 & 12.50 & $7.76^{* * *}$ & 5.56 & 6.87 & \multirow{3}{*}{.23} & 6.40 & 8.55 & \multirow{3}{*}{.54} & 3.95 & 5.25 & \multirow{3}{*}{$3.4^{*}$} & 11.61 & 8.12 & $4.47^{*}$ & 7.30 & 6.32 & \multirow{3}{*}{.40} & 2.48 & 3.74 & \\
\hline & 中頻度 $(\mathrm{n}=118)$ & 11.94 & 10.71 & 低彩度〉中 & 5.19 & 5.01 & & 5.50 & 6.33 & & 3.58 & 5.84 & & 10.43 & 7.18 & 低頻度 & 6.90 & 5.20 & & 3.01 & 5.09 & .47 \\
\hline & 高頻度 $(\mathrm{n}=173)$ & 11.06 & 10.96 & 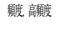 & 5.03 & 5.74 & & 5.47 & 6.82 & & 2.40 & 4.24 & & 8.79 & 7.16 & >高頻度 & 6.62 & 5.85 & & 2.55 & 4.41 & \\
\hline \multirow[t]{3}{*}{ 部員数 } & 小規模 $(\mathrm{n}=130)$ & 11.72 & 10.17 & & 5.35 & 6.39 & & 5.10 & 6.37 & \multirow{4}{*}{.75} & 2.66 & 4.13 & \multirow{4}{*}{1.55} & 10.42 & 7.74 & & 6.88 & 6.00 & \multirow{3}{*}{.25} & 3.08 & 4.66 & \\
\hline & 中規模 $(\mathrm{n}=130)$ & 12.00 & 11.50 & 1.93 & 5.17 & 5.38 & .07 & 6.15 & 7.82 & & 3.72 & 6.12 & & 9.25 & 6.91 & .85 & 7.08 & 6.03 & & 2.74 & 4.86 & 1.35 \\
\hline & 大規模（n=113） & 14.37 & 12.60 & & 5.07 & 5.55 & & 5.82 & 6.98 & & 2.93 & 4.61 & & 10.14 & 7.73 & & 6.57 & 5.14 & & 2.14 & 3.81 & \\
\hline \multirow{3}{*}{$\begin{array}{l}\text { 過去 } 3 \text { 年 } \\
\text { 間の成績 }\end{array}$} & 市大会 $(\mathrm{n}=167)$ & 13.23 & 11.62 & & 5.32 & 5.69 & & 5.14 & 6.83 & & 3.56 & 5.82 & & 9.80 & 6.93 & & 7.73 & 6.12 & $5.17^{*}$ & 2.28 & 3.90 & \\
\hline & 県大会 $(n=149)$ & 12.98 & 11.31 & 1.96 & 5.44 & 6.12 & .97 & 6.34 & 7.49 & \multirow[t]{2}{*}{1.12} & 2.85 & 4.03 & \multirow[t]{2}{*}{1.28} & 10.19 & 8.09 & .17 & 6.59 & 5.46 & 㠲会闃 & 3.07 & 4.94 & 1.24 \\
\hline & 関東大会以上 $(n=57)$ & 9.88 & 11.03 & & 4.23 & 5.12 & & 5.58 & 6.67 & & 2.49 & 5.00 & & 9.61 & 7.32 & & 5.00 & 4.92 & 欶会灴上 & 2.82 & 4.88 & \\
\hline \multirow{3}{*}{$\begin{array}{c}\text { 土日の } \\
\text { 活動時間 }\end{array}$} & 4 時間未満（n=90） & 11.20 & 11.30 & \multirow{3}{*}{1.14} & 6.27 & 7.18 & & 6.01 & 8.53 & \multirow{3}{*}{.92} & 2.86 & 5.22 & \multirow{3}{*}{.16} & 9.03 & 6.50 & & 7.40 & 6.51 & & 3.04 & 5.45 & \\
\hline & 半日：4時間以上 $(n=252)$ & 13.23 & 11.54 & & 4.84 & 5.27 & 2.04 & 5.40 & 6.21 & & 3.18 & 4.89 & & 9.98 & 7.56 & 2.02 & 6.58 & 5.43 & .92 & 2.36 & 3.84 & 2.80 \\
\hline & 概权全日（n=31） & 11.77 & 10.95 & & 5.03 & 5.04 & & 7.10 & 8.96 & & 3.32 & 5.94 & & 12.13 & 8.87 & & 7.55 & 5.98 & & 4.23 & 5.98 & \\
\hline
\end{tabular}

【部員数 : 小規模 $=5$ 人 24 人, 中規模 $=25$ 人 40 人, 大規模 $=41$ 人 120 人】，【指導頻度 : 低頻度 $=1 \sim 2$ 日 $/$ 週，中頻度 $=3 \sim 4$ 日 $/$ 週，高頻度 $=5 \sim 7$ 日 $/$ 週】

を示している.「活動意欲の低い部員」では, 20歳代と50歳以上に有意な差が認められ，20代 の方が高い得点を示した.「学校内雲囲気との 相違」では30歳代が, 20歳代と50歳以上より有 意に高い得点を示した。指導教科では, 保健体 育とその他の指導教科による比較を行った. 結 果,「部活動の時間的負担」（ $\mathrm{t}=2.62, \mathrm{p}<.05)$ に有意な差がみられ, その他教科の方が保健体 育に比べ高い得点であった，校内での役職有無 による比較では,「部員との意思疎通困難」( t $=3.14, \mathrm{p}<.05)$ に有意な差がみられた. 役職 なしの方が, 役職ありに比べ高い得点であった。 部活動での役職では, 「学校内雲囲気との相違」 $(\mathrm{t}=3.35, \mathrm{p}<.05)$ において顧問の方が, 副 顧問に比べ有意に高い值を示した，顧問の過去 の競技経験有無による比較では,「指導時間の 不足」（ $\mathrm{t}=2.06, \quad \mathrm{p}<.05)$ に有意な差がみら
れた，過去に経験がある顧問の方が，過去に経 験がない顧問に比べ有意に高い值を示した，顧 問の指導頻度による比較では, 1 週間のうちに 1 日·2 日指導する顧問を低頻度指導群, 3 日・ 4 日指導する顧問を中頻度群, 5 日以上指導す る顧問を高頻度群と分類して分析を行った。 そ の結果,「部活動の時間的負担」 $(\mathrm{F}=7.76, \mathrm{p}$ <.001）と「他の指導者との人間関係の悪さ」 $(\mathrm{F}=3.40, \mathrm{p}<.05),\lceil$ 指導時間の不足」 $(\mathrm{F}=$ 4.47, $\mathrm{p}<.05 ）$ に有意な差が認められた. 多重 比較の結果,「部活動の時間的負担」では中頻 度群と高頻度群に比べ, 低頻度群が高い值を示 した.「他の指導者との人間関係の悪さ」では, 多重比較の結果ではいずれにおいても有意な差 を示さなかった。「指導時間の不足」では低頻 度群が高頻度群と比較し, 有意に高い值を示し た. 過去 3 年間の成績による比較では, 「活動 
意欲の低い部員」（ $\mathrm{F}=5.17, \mathrm{p}<.05 ）$ に有意 な差が認められた。多重比較の結果, 市大会出 場経験部活動の顧問より, 関東大会出場経験部 活動の顧問の方が低い值を示した.

\section{5. 考察}

本研究の目的は, 顧問が部活動において認知 しているストレッサーを明らかにし，ストレッ サー尺度の作成を試みることであった。 さらに 顧問や部活動の属性間の比較を行い，属性間の ストレッサー認知の違いを明らかにすることを 目的としていた，分析の結果, 顧問のストレッ サーは 7 因子構造であることが明らかとなり， 作成された尺度の妥当性と信頼性の検討が行わ れ, 許容可能なモデルとして採用された。 また, 属性によってストレッサーの認知に違いが存在 することが明らかとなった。

本研究は, 先行研究 ${ }^{171)(8)}$ 25) を参考にストレッ サーに関する項目を作成し, 部活動の顧問歴が 20 年以上の中学校教師 2 名と部活動の施策にも 精通しているスポーツ政策の専門家 1 名, ス ポーツ政策を専攻とする大学院生 6 名の計 9 名 によって内容的妥当性を確認した. 分析に際し てはIT相関分析を行い, 基準值を満たした弁 別性の高い項目を用いた. 弁別力が確認された 36項目を用いて探索的因子分析（主因子法，プ ロマックス回転）を行った結果，7因子構造が 得られた. 探索的因子分析で得られた 7 因子構 造を仮説モデルとし, 確認的因子分析を行った 結果, 構成概念妥当性および内容的妥当性等 の総合的な観点から， 7 因子構造が妥当性のあ る許容可能なモデルとして採用された。また, Chronbachの $a$ 係数は, 全ての因子で基準值 を満たし信頼性が確認された。以上より，一部 の妥当性に課題を残すものの, 妥当性と信頼性 を有した顧問のストレッサー尺度が作成できた といえる。 さらに, 本研究では尺度の簡便性と 先行研究からの指摘 ${ }^{37)}$ を考慮し尺度作成を行っ た。また，本研究で用いられたサンプルは，B 市内の地域と学校規模に偏りが無いよう考慮し て抽出が行われている。 よって, 作成された尺
度は利便性と沉用性が比較的高いことが推察さ れる。

顧問のストレッサーとして, 部活動への従事 を負担に感じることを示す「部活動の時間的負 担」が第 1 因子として抽出された。高校運動部 活動顧問教員の悩みや負担として，「時間的負 担」に加え「金銭的負担」「体力的負担」の力 テゴリーが抽出されている ${ }^{25)}$. 本研究において は, 探索的因子分析の結果から, 部活動におけ る負担として最も因子負荷量が高かった 4 項目 は「土日は半日に指導や練習試合があり，自分 の時間に余裕が無いこと」「自分の時間（趣味 など）がなかなか持てないこと」など, 時間的 負担に関する項目であった。顧問は時間的な従 事に対する対価として金銭的な手当を求め，部 活動の指導を長時間行うことによって体力的な 負担を感じていることが推察できる。つまり, 時間的負担が最も部活動における負担として説 明できる要因と考えられる。ささらに，「部活動 の時間的負担」は保健体育科以外の教科を指導 している顧問にとってょり衝撃性の強いスト レッサーであることが明らかとなった，教師の 勤務時間外に多く行う職務として, 教材研究等 の授業準備が挙げられている2 3). このことか らも, 教科別による教材研究等の他の職務に費 やす時間の違いが関連していると考えられる. また, 指導頻度が少ない顧問がよりストレッ サーとして強く認知している. ラザルス・フォ ルクマン ${ }^{27)}$ の認知的評価モデルにおいて, スト レスは心理的な認知プロセスと生理的変化や情 緒的変化を伴うストレス反応の全体的な過程と して捉えられている。 また，ストレス反応の発 生が慢性化した場合, 心身の疾患や社会的失敗 などの結果を生じさせる可能性も指摘されてい る. したがって, 指導頻度が低い顧問の方が「部 活動の時間的負担」をストレッサーとしてより 強く認知しているという本研究の結果は, 顧問 自身にとって部活動に従事することは対処困難 な状況であると感じ, 結果として部活動の指導 頻度を少なくするという行動をとっている可能 性を示唆している。ただし，より詳細な因果関 
係を明らかにするためには, 対処可能性の認知, ストレス反応, 指導頻度を全体的な認知プロセ スと行動の関係でとらえる必要があり, 縦断的 な研究が求められる.

顧問は部員との意思疎通がうまく図れていな いことをストレッサーとして認知していること を示す,「部員との意思疎通困難」が第 2 因子 として抽出された。コーチが認知する組織スト レッサーの「チーム」に関わるストレッサーの 一つに「コミュニケーション」が抽出されて いる ${ }^{21)}$.「コミュニケーション」は選手や他の 指導者, チーム組織の運営側との関係性が久如 していることを示している. また, 中学校の教 師が抱える生徒との人間関係の悩みに着目した 研究では,「生徒への抵抗感」「指導上の困難」 「生徒からの非受容感」「関わり不全感」を抱い ていることが明らかとなっている38).このよう に, 指導対象者との意思疎通が上手くいかない ことは指導者にとってはストレッサーであり， 運動部活動においても顧問は部員との意思疎通 がうまくいかないことをストレッサーであると 認知しているといえる.さらに本研究におい ては, 校内で主幹や主任といった責任ある役職 を担っている顧問の方が, 役職がない顧問に比 べ,「部員との意思疎通困難」の得点が有意に 低い值を示した．大学競技スポーツの研究にお いて Frey ${ }^{40)}$ は, コーチの個人的要因や周囲の 状況がストレッサーの認知に関連しているとし た.さらに，そういった個人的要因や周囲の状 況が, コーチのストレッサーの認知やストレス 反応といった全体的な過程において, 抑制要因 となり得ることが指摘されている20). 一方, 教 師においても, 個人的要因としての「キャリア 適応力」は, 職業ストレッサーの認知を抑制す $ろ^{16)}$ ことが示されており, 教師の年齢や校務分 掌, 職位の関連による職務の性質の違いが, ス トレッサーの認知に影響を与えることが示唆さ れている. 以上の様な先行研究の知見から, 役 職を有する顧問は, 役職を担うことで得られる 責任感や職務内容, さらには学校内における生 徒との関わりといった経験から学び, 部活動に
おいて部員との関係性の中で意思疎通がうまく いかないことが生じても対処可能であり, 弱い ストレッサーとして認知していることが考えら れる.

「保護者の批判的態度」が第 3 因子として抽 出された. 先行研究 ${ }^{1718)}$ においても保護者に関 連するストレッサーが抽出されており，保護者 に関するストレッサーは，日本の教育現場にお ける特徵的なストレッサーであることが指摘さ れている ${ }^{19)}$. 本研究から, 運動部活動において も保護者が顧問のストレッサーとして認知され ることが考えられる，保護者は運動部活動を成 立させている要因の一つであり, 時に運動部活 動の存廃を左右するほど影響力を持つことがあ $ろ^{5)}$. 本研究では, 保護者が顧問に対しても影 響を与える可能性が示唆された。保護者の顧問 の指導の在り方に対する不満や批判が, ス卜 レッサーとして顧問に認知され，顧問の心理や 行動に影響を与えている可能性が考えられる.

教師やコーチにおいても職場内における同僚 との対人関係に関わるストレッサーが確認され ている ${ }^{1213115) 19) 211}$ 。本研究において抽出された 「他の指導者との人間関係の悪さ」も職務にお ける対人的なストレッサーの一種であることが 考えられる。顧問は，他の指導者の指導内容や 価值観が自身と異なる時にストレッサーを認知 することがあり，意思疎通が図れないことで本 来協力するべき指導者同士が上手く連携を取れ ていない可能性が考えられる，属性間の比較の 結果, 一元配置分散分析では指導頻度に有意な 差が確認された. 部活動への指導頻度と, 他の 指導者との人間関係は関連していることが示唆 されるが, 多重比較検定においては有意な差は 示されなかった為, 結果の解釈には留意が必要 である。

運動部活動の顧問が指導に際して最も問題, もしくは課題と感じていることに「校務が忙し くて思うように指導ができない」が報告されて いる ${ }^{8)}$. 本研究により, 顧問はそのような部活 動の指導時間不足をストレッサーと認知してい ることが明らかとなった。 小・中学校の教師が 
実施困難な職務に対してストレッサーを認知し

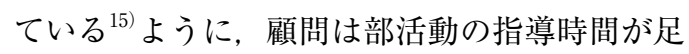
りず，思うように指導ができない状況をスト レッサーと認知していることが考えられる。さ らに, 指導頻度が少ない顧問の方が, 指導時間 不足をストレッサーとしてより強く認知してい るという属性間比較の結果は, 指導時間の確保 に悩む顧問の実態を表していると言える. 一方 で，当該部活動の競技経験がある顧問の方が, 経験のない顧問より，「指導時間の不足」をス トレッサーとして強く認知している. 上述した 運動部活動顧問が抱える問題・課題では, 体 育以外の担当教科で, 競技経験もない顧問の み，「校務が忙しくて思うように指導ができな い」が 2 番目に多く挙げられている ${ }^{8)}$. 本研究 では，指導教科による有意差は「部活動の時間 的負担」で確認されているが,「指導時間の不足」 においては確認されなかった。「指導時間の不 足」への認知には競技経験の有無が, 関連する 顧問の属性であることが示された．また，年代 による関連も示唆された. 特に30歳代の顧問の 方が, 若手の 20 歳代やベテランの50歳代以上と 比べ, 指導時間が不足していることをより強く ストレッサーとして認知している. 若手の 20 歳 代より30歳代の顧問の方がストレッサーとして 強くされているのは, 年齢に伴い教師としての 職務内容や学校内における役割の変化が関連し ている可能性が考えられる．30歳代より50歳代 の顧問の方が低いのは, 実際に体を動かした実 技指導などが可能かどうかといった部活動の指 導方法が関連していることも理由として考えら れる。

教師が職務において感じるストレッサーの 1 つとして，児童生徒の態度や意識に関連する

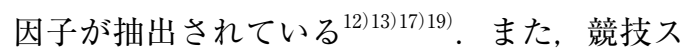
ポーツにおけるコーチのストレッサーとしても 選手のパフォーマンスや意識, 態度や行動など が抽出されている ${ }^{2021)}$. 本研究においても,「活 動意欲の低い部員」の因子が抽出され, 顧問は 部員の練習や競技に取り組む意識や態度に対し てストレッサーを認知していることが明らかと
なった. 20歳代の顧問の方が50歳以上の顧問よ り, 活動意欲の低い部員に対する指導にスト レッサーを認知していることから, 経験年数が 若い顧問は, 部活動指導の方向性に悩むという 運動部活動特有の葛藤 ${ }^{10)}$ を抱えている可能性が 考えられる。 また, 過去 3 年間に, 関東もしく は全国大会に出場経験がある部活動を担当して いる顧問より，市大会出場の部活動を担当して いる顧問の方が, 部員の活動意欲が低いことを ストレッサーとして強く認知している．活動意 欲が低い部員が所属する部活動も，大会への参 加に際しては先ず市の大会から参加となる。こ のような大会の仕組みを考えると，競技力の高 い部活動には比較的活動意欲の高い部員が所属 していることが推察される. したがって, 部活 動の競技力は部員の活動意欲と大いに関連して いることが考えられ, 部員と顧問の活動意欲の 差が影響していることを示す結果と言える.

渋倉 ${ }^{25)}$ は「活動環境」のカテゴリーにおいて, 「学校の雲囲気」のグループを抽出している. 本研究では構成概念として, 同僚や管理職との 価值観の違いや不理解などを示す「学校内雲囲 気との相違」が抽出された. 校長からのソーシャ ル・サポートの認知が教師のストレス反応を緩 和させる可能性があり ${ }^{42}$, 教師のバーンアウト には組織特性や同僚との関係が影響しているこ と ${ }^{15)}$ な゙, 学校内との䨌囲気と教師のストレス 反応との関連性が確認されている。このことか らも，部活動に取り組む顧問に対して管理職や 同僚からの支援が無いことや，部活動に対する 志向性の違いといったような学校内の部活動に 対する䨌囲気が時に顧問にとってストレッサー と認知される可能性が示唆される。.さらに, 副 顧問より顧問の方が，50歳以上の顧問より30歳 代の顧問の方がストレッサーとして強く認知し ている．部活動における役職が部活動に対する 責任感に違いを生み, 顧問自身と学校内の部活 動に対する考え方の違いに，よりストレッサー を強く認知していることが示唆される．また, 部活動に対する考え方や取り組み方が30歳代と 50歳以上の顧問では異なることが影響している 
と推察されるが, 本研究ではその詳細について 言及することはできない.

本研究においていくつかの限界が指摘でき る.まず指摘できるのは, 配布方法の限界であ る. 本研究は $\mathrm{A}$ 県 $B$ 市の教育委員会を介して学 校単位で配布回収を行った。顧問教員が社会的 に望ましい回答を行っている可能性は否定でき ない. 今後は, 回収方法に工夫が必要といえよ う. 例えば, 教育委員会を介さずに直接回収し， その旨を質問紙に提示するといった対策が考え られる. また, 本研究では中学校の顧問（週に 1 回以上指導）のストレッサー尺度を作成する ことを目的としたため, 高校の顧問や, 部活動 の指導は行わず部活動の運営管理のみを行って いる顧問については言及することができない。 本尺度を高校の顧問に適用させる場合には結果 解釈に留意が必要である.ささらに, 本研究によっ て作成された尺度は，内的基準によって妥当性 が検討された，ストレスは全体的なプロセスで とらえることが重要であるという指摘 ${ }^{27)}$ を踏ま えると, 今後はバーンアウトやストレス反応等 の基準関連妥当性の検討を行っていくことで, より妥当性の高い検証が可能となる.

\section{6.おわりに}

本研究では, 運動部活動顧問のストレッサー を明らかにし, ストレッサー尺度を作成するこ とが目的であった。結果, 運動部活動顧問のス トレッサーとして「部活動の時間的負担」「部 員との意思疎通困難」「保護者の批判的態度」「他 の指導者との人間関係の悪さ」「指導時間の不 足」「活動意欲の低い部員」「学校内䨌囲気との 相違」の 7 因子が抽出され, 顧問のストレッサー 尺度が作成された。 また, 運動部活動の顧問は 専門性を有しているほど指導時間が足りないこ とにストレッサーを抱いているなど, 顧問の属 性によるストレッサーの認知の違いが明らかと なった．今後, 顧問が認知するストレッサーと 部活動に対する態度等を示す心理的な変数との 関連を検証することで, 学校の運動部活動顧問 の配置計画や外部資源の導入など, 運動部活動
のマネジメントに有効な示唆を提示することが できると考えられる。よっ，運動部活動のあ り方を検討する際には，指導者の指導実態のみ ならず，指導者の心理的な側面とその行動の関 係性に着目していくことも重要な意義を有して いることが考えられる.

（注 1 ） 久保 ${ }^{9)}$ によると, 部活動における指導者は 「コーチ」もしくは「教師」として明確に位置づ けることはできないとしている. 本稿では, 教 師として学校の職務をおこないつつもコーチと して部活動に携わる指導者を研究の調査対象と するが,「外部指導者」との混乱を避けるため「顧 問教師」,「顧問」として表記する.

（注 2 ）関東地域の A 県 B市では, 時間外勤務の部 活動手当支給額として次の時間区分が設定され ている. 1）8時間以上；日額5,000円，2） 4 時間以上 8 時間未満；日額2,500円，3） 2 時間 以上 4 時間未満；日額1,500円，4） 1 時間以上 2 時間未満；日額1,000円. また，約70\%～80\% の中学校運動部活動が, 土日において 2 時間〜 4 時間未満の活動を行っている 土日における活動時間は 4 時間の区切りの選択 肢を設定することが妥当であると判断した。ま た，上記の手当支給額時間区分規定が存在する ことから，ストレッサー項目の内容的妥当性を 確認している中学校教員 2 名により,「概ね全日」 の表記が 8 時間以上であると認識できると判断 された。なお，選択肢における時間は土日それ ぞれ 1 日当たりの活動時間を示す.

（注３）経験率は出来事を経験したサンプルの割合 を示し,「1. 全くなかった」以外の回答の比率 を表す. 同様に, 嫌悪率は「1. 全く嫌ではなかっ た」以外の回答の比率を表す.

\section{参 考 文 献}

1) 文部科学省 ; 運動部活動の在り方に関する調 查研究協報告書, 運動部活動の在り方に関す る調査研究協力者会議, 2013, (2014年12月22 日取得 ), http : //www.mext.go.jp/a_menu/ sports/jyujitsu/__icsFiles/afieldfile/2013/ 05/27/1335529_1.pdf.

2 ) ベネッセ; 平成18年度教員勤務実態調査（小· 中学校), 2006, (2014年12月22日取得), http： 
//berd.benesse.jp/shotouchutou/research/ detail 1 .php?id=3261.

3 ) 岡田一秀; 教員の多忙化と時間外勤務につい ての調查研究, 学校メンタルヘルス, Vol.13, No. 1, pp.59-62, 2010.

4) OECD (経済協力開発機構); 教員環境の国際 比較 - OECD 国際教員指導環境調査 (TALIS) 2013年調査結果報告書, 国立教育政策研究所編, 明石書店, 2014.

5 ）中澤篤史; 運動部活動の戦後と現在一なぜス ポーツは学校教育に結び付けられるのかー（第 3 版). 青弓社, 2014.

6 ）神谷 拓; 運動部活動の制度史と今後の展 望, 体育科教育学研究, Vol.30, No.1, pp.75-80, 2014.

7 ) 関喜比古; 問われている部活動の在り方一新 学指導要領における部活動の位置づけ一, 立法 と調査, 291号, pp.51-59, 2009.

8 ）公益財団法人日本体育協会; 学校運動部活動指 導者の実態に関する調査報告書, 2014, (2014年 12月22取得）http : //www.japan-sports.or.jp/ Portals/0/data/katsudousuishin/doc/houkokusho. pdf.

9) 久保正秋：コーチング論序説 - 運動部活動 における「指導」概念の研究一, 不昧堂出版, 1998

10）小谷克彦, 中込四郎；運動部活動において指導 者が遭遇する葛藤の特徵, スポーツ心理学研究, Vol.30, No.1, pp.33-46, 2003.

11）文部科学省; 運動部活動の在り方に関する調 查研究報告, 中学生・高校生のスポーツ活動に 関する調査研究協力者会議, 1997, (2013年 8 月 23日取得）http：//www.mext.go.jp/b_menu/ shingi/chousa/sports/001/toushin/971201. $\mathrm{htm}$.

12) Kyriacou. C., Sutcliffe. J. ; A Model of Teacher Stress, Educational Studies, Vol.4, No.1, pp.1-6, 1978.

13) Mrak G. Borg et al. ; Stress in Teaching : A Study of Occupational Stress and Its Determinants, Job Satisfaction and Career Commitment among Primary Schoolteachers, Educational Psychology, Vol.11, No.1, pp.59-75, 1991.

14) Robert M. Klassen, Ming Ming Chiu; Effects on Teachers' Self-Efficacy and Job Satisfac- tion: Teacher Gender, Years of Experience, and Job Stress, Journal of Educational Psychology, Vol.102, No.3, pp.741-756, 2010.

15）高木亮, 田中宏二 ; 教師の職業ストレッサーに 関する研究, 日本教育心理学研究, Vol.51, No.2, pp.165-174, 2003.

16）高木亮, 教師の職務暮藤とキャリア適応能力が 教師のストレス反応に与える影響の検討 - 年 代ごとの影響の比較を中心に一, 教育心理学研 究, Vol.56, pp.230-242, 2008.

17）田中輝美,他 ; 教師用ストレッサー尺度の開発, 筑波大学心理学研究, Vol.25, pp.141-148, 2003.

18）塚本伸一; 教師ストレッサー尺度作成の試み, 立教大学臨床心理学研究, Vol.4, pp.1-9, 2010.

19）西坂小百合；我が国に扮ける教師ストレス研 究の現状と課題, 学校教育学研究論集, Vol.8, pp.13-24, 2003.

20) David Fletcher, Michael Scott; Psychological Stress in Sports Coaches: A Review of Concepts, Research, and Practice.Journal of Sports Sciences, Vol.28, No.2, pp.127-137, 2010.

21) Richard C. Thelwell at al. ; Stressor in Elite Sport: A Coach Perspective. Journal of Sports Sciences, Vol.26, No.9, pp.905-918, 2008.

22) Richard C. Thelwell et al. ; Coping with Stressors in Elite Sport: A Coach Perspective.European journal of sport science, Vol.10, No.4, pp.243-253, 2010.

23）渋倉崇行, 森 恭; 高校運動部員の心理的久 トレス過程に関する検討, 体育学研究, Vol.49, No.6, pp.535-545, 2004.

24）渋倉崇行, 他 ; 高校運動部員の部活動ストレッ サーに対する認知的評価尺度の再構成. 体育学 研究, Vol.53, No.1, pp.147-158, 2008.

25）渋倉崇行；高校運動部活動顧問の悩み事や負 担の実態：ストレッサー尺度開発に向けた予 備的研究, 人間生活学研究, Vol.4, pp.91-99, 2013.

26）文部科学省; 平成 26 年度学校基本調査, 調査 結果の概要（初等中等教育機関, 専修学校 · 各種学校), 2014, (参照日2014年12月22日) http://www.mext.go.jp/component/b_menu/ houdou/__icsFiles/afieldfile/2014/08/07/ 1350732_02.pdf. 
27）リチャード S.ラザルス, スーザン フォルクマ ン：本明寬, 他監訳 ; ストレスの心理学 - 認知 的評価と対処の研究一, 実務教育出版, 1984.

28）新美明夫, 植村勝彦; 心身障害幼児をもつ母親 のストレスについて：ストレス尺度の構成, 特 殊教育学研究, Vol.18, No.2, pp.18-33, 1980.

29）橋本剛；大学生における対人ストレスイベン 卜分類の試み, 社会心理学研究, Vol.13, No.1, pp.64-75, 1997.

30）島津明人, 他 ; 従業員を対象としたストレス調 査票作成の試み (1) ストレッサー尺度・ストレ ス反応尺度の作成, 産業ストレス研究, Vol.4, pp.41-52, 1997.

31）岡安孝弘, 他; 中学生の学校ストレッサーの 評価とストレス反応との関係, 心理学研究, Vol.63, No.5, pp.310-318, 1992.

32）徳永幹雄; 第52回大会キーノートレクチャー： 体育心理学「体育・スポーツにおける心理 尺度開発の動向と展望」, 体育学研究, Vol.47, pp.479-484, 2002.

33) Susan A. Jackson, Herbert W. Marsh ; Development and Validation of a Scale to Measure Optimal Experience: The Flow State Scale, Journal of Sport and Exercise Psychology, Vol.18, pp.17-35, 1996.

34）小塩真司; 研究事例で学ぶSPSS と Amosによ る心理・調查デー夕解析 (第 2 版), 東京図書, 2012.
35）南風原朝和；モデル適合度の目標適合度 - 観 測変数の数を減らすことの是非を中心に一, 行 動計量学, Vol.29, No.2, pp.160-166, 2002.

36) 豊田秀樹; 共分散構造分析 [Amos 編] (第 7 刷), 東京図書, 2014.

37) Claes Fornell, David F.Larcker ; Evaluating Structural Equation Models with Unobservable Variables and Measurement Error, Journal of Marketing Reserch, Vol.18, pp.39-50, 1981.

38）都丸けい子, 庄子一子 ; 生徒との人間関係にお ける中学校教師の悩みと変容に関する研究, 教 育心理学研究, Vol.53, pp.467-478, 2005.

39）四方健二他；小学校教師の体育授業に対する コミットメントを促す要因の質的研究, 体育学 研究, Vol.58, pp.45-60, 2013.

40) Melinda Frey ; College Coache's Experiences With Stress-“Problem Solvers” Have Problemes, Too, The Sport Psychologist, Vol.21, pp.38-57, 2007.

41）長谷部慶章他; 小・中学校における特別支 援教育コーディネーターの役割ストレスに 関連する要因, 特殊教育学研究, Vol.49, No.5, pp.457-467, 2012.

42）迫田裕子他；教師が認知する校長からのソー シャル・サポートに関する研究, 教育心理学研 究, Vol.52, pp.448-457, 2004. 